\title{
Chapter 9 \\ Diverging Perspectives on "Integration" in the Vocational Education System: Evidence from an East German Periphery
}

\author{
Birgit Glorius and Anne-Christin Schondelmayer
}

\subsection{Introduction}

In 2015, around 890,000 asylum seekers reached Germany, the majority of them aged 25 and younger (BMI 2016: 15). Among them, there were a large number of children and adolescents under 18 who had the fundamental right to receive (and also the duty to attend) school education. Due to years of war in their home countries or a poor educational system, many of them had received limited years of schooling and thus lagged behind their age peers in Germany who had pursued a continuous educational biography. This is also true for the large groups of young adults under 25, who could not finish their degree programmes in their home countries and now needed opportunities to catch up. This chapter presents results from an empirical case study carried out in 2016 in two vocational schools in a remote, rural district of East Germany. During the last decades, the region had experienced population losses rather than net migration, and there were few experiences with the integration of foreigners. Even though theoretical knowledge and concepts existed, they were not embedded in the actual experience of teachers and headteachers.

Our research aimed to evaluate the practical implementation of a programme for continuous language education, which had been used for the integration of migrant children for a long time. However, its implementation with a group of young refugees who entered the German school system at the ages of 14-17 was rather novel. During the year of our research, we accompanied stakeholders who collected and

\footnotetext{
B. Glorius $(\square)$

Institute of European Studies and History, TU Chemnitz, Chemnitz, Germany

e-mail: birgit.glorius@phil.tu-chemnitz.de
}
A.-C. Schondelmayer
Department of Education Sciences, Section Heterogeneity, University Koblenz-Landau, Landau, Germany
e-mail: schondelmayer@uni-landau.de


reflected upon first experiences, and observed the development of structures and regulations for this educational field and this specific group. In this chapter, we will first show how the implementation and outcome of the concept is linked to the interpretation of stakeholders on site, who are not always ready to apply conceptual approaches that were developed without consultation with them. Second, we will highlight that the definition of integration not only varies on an individual level, but that it is entangled with social positions and roles. Third, we will show how the specifics of the locality affect integration processes, taking into account regional characteristics like the shape of the labour market, population structures, and perceptions of and public discourses on migration and asylum.

To tackle those aspects, we address the following guiding questions:

What idea of "integration" is present in the narration of the main stakeholders?

How is this interpretation framed?

How do varying interpretations of "integration" influence the practices of integration?

In order to address these questions, we will first elaborate upon the notion of "integration" from the perspective of various disciplines and their development (Sect. 9.2). Section 9.3 will address the policies and regulations for the education of migrant children and recent policy changes due to the arrival of refugees. Section 9.4 discusses the regional settings of our case study, our research methodology and implementation, and Sect. 9.5 turns to the results of our case study, which are discussed and generalized within a wider explanatory frame in the final section (9.6).

\subsection{Perspectives on Integration and Its Implications for Educational Planning}

The notion of "integration" has manifold meanings and interpretations, which vary throughout societal groups, professions, and over time. Generally speaking, integration means the connection of single parts within a system, like for example a social system. When all parts are connected with each other, the system can be understood as being a whole and can be identified by its clear delimitations with respect to other systems (Esser 2000). Following social theory, the differentiation between the systemic level and the actors' level is of crucial importance for understanding integration processes. While system integration, according to Lockwood (1964: 245), means "the orderly or conflictful relationships between the parts", social integration characterizes "the orderly or conflictful relationships between the actors" of a social system. Social psychology uses the term integration for the description of intergroup relations (Berry 1984). Pettigrew (1988) defines "integration" as "intergroup interaction that involves social processes that facilitate both intragroup integrity and intergroup relations" (Pettigrew 1988: 19). Both social theory and social psychology stress the importance of social structures and human (individual or group) interactions for the process of integration. More specifically, social theory distinguishes three main mechanisms of social integration: 
1. culturation, which means that the actors need to acquire specific knowledge and competences (like language skills) to get into contact with other actors;

2. placement, which means the assignment of a specific social position; and

3. interaction, which means the mutual orientation of actors with the help of shared knowledge, symbols, daily communication and emotions.

Following the mechanisms of social integration, schools seem to be the ideal place for integration processes, as they offer knowledge and skills which are relevant for integration, and provide an overall accepted social identity (as students) to their members, as well as opportunities for interaction in a shared environment.

In the context of migration, the term "integration" is frequently equated with "assimilation", especially in political and public discourse (Bowskill et al. 2007, Hersi 2014), or when referring to specific aspects like culture and religion (see Schneider and Crul 2010:1145). This perspective is criticized from the field of pedagogics, because those framings of both assimilation and integration are based on the assumption of a deficient "other", who can only enter a given structure by abandoning his/her own norms, values and habits, and instead adopting the norms and values of the host society. It also denies ongoing societal changes, which result in a higher social divergence and the creation of new identities. The assimilation approach conceptualizes the host society as a homogeneous entity, which is threatened by the addition of other, foreign cultures. Thus, already existing differences in the host society are neglected (Nohl 2010: 17ff). In this perspective, integration is a process of determining and distinguishing between the inside and the outside, the "we" and the "other", or the "local" and the "stranger" (Riegel 2009: 24), and therefore contributes to a process of exclusive identification and essentialization.

Taking a transatlantic comparative perspective on discourses and processes of migration and integration, Schneider and Crul (2010) point to the varying interpretation of the terms "assimilation" and "integration" in the US and Europe. In the US, the term assimilation refers to the idea that all groups of immigrants and their offspring can become similar ("the mainstream"), which basically means to be incorporated into a dynamically developing system (like the immigrant society of the nineteenth and early twentieth century). "Studying 'successful 'assimilation' thus has mainly meant to measure the degree of incorporation into patterns of economic and social "success" (Schneider and Crul 2010: 1144). In the European context, on the other hand, this dynamic and inclusionary perspective of "assimilation", especially in terms of economic performance, is often overlooked. "European "integration' predominantly carries the implicit ideal of (a minimum degree of) cultural homogeneity especially referring to language as a prerequisite for social cohesion" (ibd.) Also, Schneider and Crul (2010) highlight the different traditions of social politics in the US and Europe. While in the US a neoliberal economy with low regulatory influences and a high self-determination of the individual prevails, the (Western) European context is especially characterized by a strong welfare state with a high number of regulations and specific policies aiming to overcome group inequalities and integrate strangers. In this framing, the term "integration" fits better, as it more explicitly includes structural aspects of incorporation into society than "assimilation" (ibd.: 1145). 
Since the late twentieth century, the transnational paradigm in migration research challenges the traditional approaches of migration and integration. The term "transnationalism" reflects migrants' lived realities, which are characterized by the expansion of their individual reference frame and social relations beyond borders, thus creating a transnational social space (Pries 1996). These processes cannot be adequately addresses by dualistic models of inclusion and exclusion, such as in traditional assimilationist approaches. Pries (2003: 32) therefore suggests an expanded model of social incorporation as an open-ended social process of economic, cultural, political and social interdependence for migrants at the local, regional, national and transnational levels. In the context of ongoing globalization and a multitude of migration processes, he argues, nation states cannot uphold models of homogenization or dominant integration paradigms any more, but should prepare for flexible processes and results of incorporation (ibd.: 33, see also Treibel 1999: 151). Incorporation in this sense entails the negotiation of self-perceptions and external perceptions, which requires a certain level of openness from all actors involved. This is in line with the post-migration paradigm, which points to societal negotiation processes that acknowledge the (irreversible) realities of immigration countries with high levels of diversity and the concomitant necessity to adapt regulatory structures, institutions and political cultures to those new realities (Foroutan 2015). However, the post-migration paradigm is more radical in challenging the conventional understanding of migration and in problematizing racist practices. In relation to educational issues, the turn towards open-ended modes of incorporation would involve a change of perspectives: Rather than asking how students need to adapt to an educational system, we would have to explore the adaptation of schools to respond to the individuality and resources of their students. This perspective brings the notion of "inclusion" to the fore-an educational approach that aims to acknowledge differing but equal ways of life on the basis of formal regulations and structural adaptations (Georgi 2015: 26). The notion of inclusion thus also implies the acknowledgement of diversity.

\subsection{The Positioning of Foreign and Asylum-Seeking Students in the German Educational System}

\subsubsection{Development of "Foreigner Education" in Germany}

The German educational system is traditionally constituted as a monolingual school system and is associated with a homogeneous and monolingual nation-state concept (Gogolin 2010: 303). ${ }^{1}$ Questions of migration, social plurality and multilingualism were considered rather late in educational planning and politics. It was not until

\footnotetext{
${ }^{1}$ In Germany, the governance of education is organized on the level of the 16 states, which results in a considerable variation regarding educational trajectories and school types. A good overview can be found at https://www.schulsystem.info/bildungssystem.html
} 
1964 that the compulsory education regulation was extended to foreign children, even though many children of the so-called "guest workers" already lived in West Germany, and it took many more years until the specifics of educating children with foreign backgrounds and non-native German speakers were seriously considered in the educational planning process (Herwartz-Emden 2007: 12). At the end of the 1960s, preparatory classes for foreigners were established in West Germany, followed by curricular developments for German as a second language, but also for the support of the children's native language, which was mainly constituted as a preparation for the anticipated return of guest workers and their families to their country of origin (Baur et al. 2004: 162). During the 1980s and 1990s, as a reaction to the numerous arrivals of ethnic German repatriates ("Spätaussiedler") and their offspring, differentiated curricula were developed for German as a second language. These curricula also established measures for labour market orientation and preparation, as well as issues of general social integration (Kühn and Gawlick 1994). In what was then the German Democratic Republic (GDR), however, specific integration programmes for migrant children were not provided. After the re-unification, most East German states adopted the West German system of stepwise integration and installed integration classes for migrant children. In the 2000s, all federal states harmonized educational planning processes in this regard and developed curricula for German as a second language, and corresponding training programmes for teachers. However, the development of an educational infrastructure for foreign minors and adults varied due to the differing shares of foreigners and changing migration processes. This is especially true for the East German states, which have a significantly lower share of population with a migration background than West German states (6.8 vs. 26.5\% in 2017) (StBA 2018). While in the 1990s a considerable infrastructure was established for the education of ethnic Germans and other migrants, this infrastructure was dismantled during the 2000s due to reduced arrival numbers of "Spätaussiedler" and asylum seekers (see Glorius 2008: 87f).

\subsubsection{Organizational Aspects of the German School System and the Placement of Migrant Children}

In general, the German school system provides 9-10 years (depending on state laws) of compulsory full-time education, followed by compulsory vocational education, which terminates when 12 years of schooling have been reached or when the student turns 18 . Above the age of 18 , students have the right to continue schooling in order to complete their secondary education, either in a "Gymnasium" which terminates with the university entrance exam, or in a vocational school, which offers general and specialized education, usually accompanied by a vocational traineeship (Fig. 9.1).

Migrant children have the same rights and obligations as non-migrant children. They receive special support to develop German language skills, mostly via preparatory classes. From there, children can gradually switch to the regular classes as 
School Type

Age

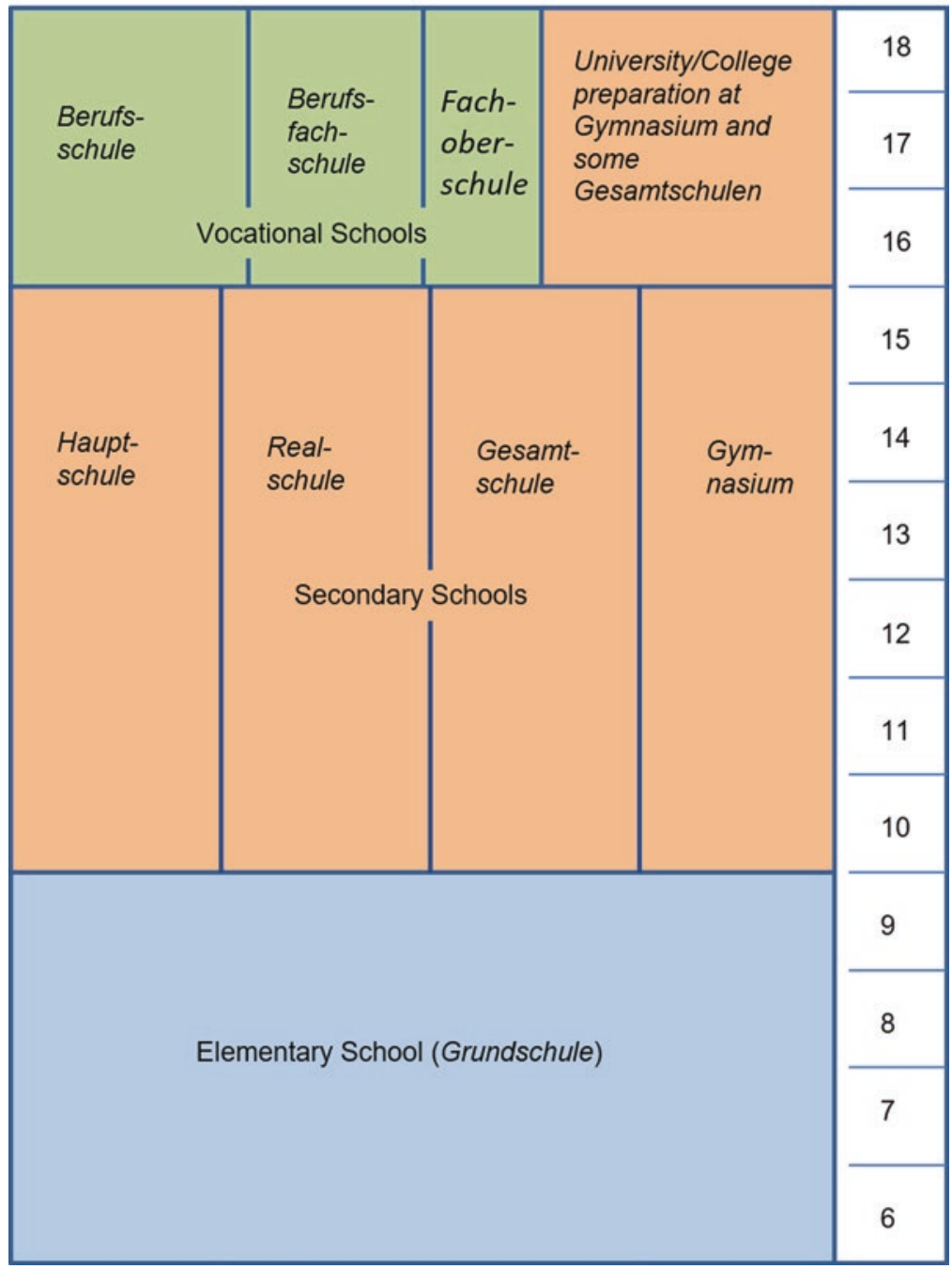

Fig. 9.1 Structure of the German educational system. (Source: HowtoGermany, at https://www. howtogermany.com/pages/germanschools.html)

soon as their language competencies are sufficient (Mercator-Institut 2015: 44ff). The success of this integration path is - among other factors - dependent on the educational age of migrant children. While children who arrive at elementary school age (6-9) have good opportunities to catch up, the situation of children who start at a later educational age is more difficult, as the German school system in most states starts with differentiated educational tracks at the age of 10 (see Fig. 9.1). Thus, most immigrant children at secondary school age are allocated to a secondary 
school that prepares for a minor educational exam (age 15 or 16 - after 9 or 10 years of schooling) rather than being enrolled at secondary schools preparing for the university entrance exam (age 18, after 12-13 years of schooling). As a consequence, children who arrive at the ages of 15 or 16 - especially those with interrupted educational biographies - are unlikely to learn German and integrate into the regular classes until tenth grade, and thus often leave secondary school without a secondary certificate.

Preparatory classes at vocational schools focus on 16- to 18-year-old students, who are perceived to be too old to integrate in regular secondary school classes. The 1-year preparatory programmes at vocational schools serve two goals: (1) they provide full-time education so that minors can fulfil their compulsory school education; and (2) they not only offer intensive German lessons but also a first orientation in the German labour market system, for example vocational education programmes. A vocational apprenticeship provides training on the job on the basis of a work contract with a specific employer. Parallel to this, trainees receive part-time education in a vocational school in order to prepare for the Chamber of Commerce exams after the termination of their 2-3 year apprenticeship.

\subsubsection{Education for Refugee Students - Quantitative Development and Qualitative Results}

Regarding asylum-seeking children, federal education laws follow the EU Reception Directive 2013/33/EU (in particular Article 14 (2)), which determines that access to the educational system must be granted no later than 3 months after an application for international protection has been made. Also, minors must be offered preparatory and language courses. The implementation of this directive is handled differently in the German states. For pragmatic reasons, allocation to a school only starts after a minor has left the first reception centre and has been allocated to a municipality, where they live during the asylum application process (Mercator Institut 2015: 37).

After years of rather moderate immigration to Germany and declining numbers of immigrant children requiring preparatory education, immigration numbers started to increase in 2007, due to increasing inner-European mobility and the arrival of refugees. And then, in 2015, Germany had 2.14 million arrivals, among them around 890,000 asylum seekers. Regarded by age groups, children and young adults under 25 were the highest share: $42.9 \%$ of all immigrants, and $55.9 \%$ of all asylum seekers (those who submitted an asylum application) (BAMF 2016: 21f). This high increase of young immigrants resulted in a rapid expansion of preparatory classes. In the state of Saxony where our case study is located, the number of students in preparatory classes more than doubled from 3751 to 7531 during the winter term 2015-2016, and the number of preparatory classes increased from 290 at the beginning of the 
school year to 469 in March 2016, of which 189 classes were located in elementary schools, 151 in secondary schools and 122 in vocational schools (Kelch 2016).

Between 2014 and 2018, a large amount of instantaneous research was carried out, delivering a first overview of major problems and issues at stake regarding the educational integration of asylum seeking students of higher age. A number of studies criticise the curricula for adolescent refugee students in vocational schools, which are mainly oriented towards language acquisition rather than general educational content, and thus leave the students ill prepared for vocational training or labour market integration (Gag and Schroeder 2014, Heinrichs et al. 2016, Paulsen et al. 2016, Vogel and Stock 2017). This is also reflected by labour market actors such as the Bavarian Industry Association, who assert that current preparatory training in vocational schools for refugee students is inadequate (vbw 2016: 242). A study from Hamburg shows how vocational schools struggle with unsuitable curricula for the vocational schooling of refugees and plea for educational approaches that are better connected to the social environment of the students (Gag and Schroeder 2014: 30).

One reason for those narrowed curricula is found in the organisation of foreigner education as such, which views preparatory language classes as a starting point, followed by stepwise integration into ordinary classes. However, as adolescent refugees can only be enrolled in schools for a limited time, due to age restrictions, they rarely reach the point of integration into ordinary classes with a regular curriculum. "While student interviews show that they appreciate the welcoming atmosphere and individualised attention in preparatory German classes, they also indicate that they miss 'real' school where they can learn subjects" (Vogel and Stock 2017: 24). Bauer and Schreyer (2016) therefore suggest a prolongation of educational opportunities above compulsory school age.

Several studies stress the significance of social contact among age peers with and without refugee backgrounds for integration success and overall well-being (Gurski and Rother 2018, Metzner et al. 2018). A study among refugee students in North Rhine-Westphalia showed that those students who were able to establish contacts with Germans outside the classroom had fewer difficulties integrating in class than those without contacts (Gurski and Rother 2018: 179). A study from a vocational school in Lower Saxony revealed that students who had continuous contact with German peers of the same age group and who were able to establish social bonds within their neighbourhood showed much higher life satisfaction (Behrensen 2007: 53).

Organisational issues are also touched upon in the recent studies, due to the multitude of actors in the field of asylum and education. Among other issues, long commuting distances from refugee accommodation facilities to schools (especially in rural regions), forced secondary mobility of refugee students resulting in re-allocation to other schools, as well as general uncertainties regarding residency and work permits for refugees, are mentioned as obstacles towards long-term integration. However, there is a great interest in integrating refugees in vocational programmes, notably in regions which are lacking a qualified labour force (Speer and Klaus 2015, Braun and Simons 2016, Scheiermann and Walther 2016). Furthermore, Heinrichs et al. (2016: 235) found problems with different cultural ideas as well as 
racism and rejection, and stressed the important role of headteachers in paving the way towards systemic integration of refugee classes in the vocational schools.

Wrapping up this section, we can say that in Germany's educational integration there has been a traditional focus on language proficiency, based on a perception of a linguistically homogeneous nation state. Regarding the layout of the educational system, there is a large and sometimes confusing variety of school types, educational programmes and regulations, which are due to the federal organisation of the state. It is obvious that the rapid increase of refugees of educational age, notably those near adolescence, challenged the existing approaches of system integration, which only proved partly ready to cope with the number and the needs of the migrants.

While this overview of existing studies has highlighted general problems, our case study will give deeper insight into the complexity of approaches, practices, and perceptions of integration.

\subsection{Case Study Background and Research Methodology}

\subsubsection{Case Study Background}

Our case study was carried out in two vocational schools in the county of Erzgebirgskreis, a peripheral, mountainous area on the border with the Czech Republic. Due to its rural and mountainous features, the region is sparsely populated: 347,665 inhabitants live in an area of $1827.9 \mathrm{~km}^{2}$. There are 61 municipalities, the largest being the county capital Annaberg-Buchholz with 20,426 inhabitants. There are six other towns with populations of between 11,000 and 18,000 inhabitants; the other municipalities are rather small, scattered settlements with poor public infrastructure, especially in terms of public transport. Like many other peripheral regions, the county of Erzgebirgskreis has suffered from population losses for decades. Especially younger adults leave the region in order to attend university or to settle in larger agglomerations, which are perceived as more attractive. However, the region is economically quite strong: it has a historic tradition of mining which laid the foundation for many other industrial sectors, such as manufacturing. In 2013, the county had 5000 small and medium-sized companies and 108,625 employees; unemployment is low, and in June 2016 there were more than 2600 open job positions. Regarding further demographic development of the county, there are serious concerns about the availability of a skilled labour force in the near future (Wirtschaftsförderung Erzgebirge 2014: 35). Accordingly, the recruitment of skilled workers, in particular in the context of vocational training, has a great significance for the future development of the region.

Due to population decline in the county and general restructuring processes following German re-unification, the structure of the public administration and the educational infrastructure has been reorganized several times. The county of 
"Erzgebirgskreis" was formed in 2008 by the fusion of four former (and smaller) counties. Also the system of state schools was reorganized several times, as a reaction to declining student numbers, but also due to changes in the economic structure which translated into students' vocational choices. At the time of writing (2018), there are three vocational schools, which are each scattered over several locations (as they served as independent schools in former times). Our two case study schools operate at five locations at a distance of between 20 and $45 \mathrm{~km}$ from each other, which constitutes a significant burden for the daily organization of lessons.

While the migration balance of the German population in Erzgebirgskreis has been negative for years, the number of foreigners has shown net gains since 2013. Foreigners also contribute positively to the age balance: in $2015,37 \%$ of the district's foreign population was younger than 25 , and only $4 \%$ were 60 years or older. From 2014 to 2015, the number of foreign children under 15 years old and adolescents between 15 and 25 years old doubled, mainly due to the arrival of asylum seekers in the county.

The extraordinary dynamics of international immigration are also reflected in changes in the duration of residency: While in 2013, $16 \%$ of foreigners had resided less than 1 year in Erzgebirgskreis and 22\% between 1 and 4 years, in 2015 these shares increased to $40.5 \%$ and $24.6 \%$, respectively. Those dynamics already shed light on the major challenges regarding the organizational aspects of education. Furthermore, as data from February 2015 suggests, asylum seekers were widely distributed across the county and resided in 39 of the 61 municipalities. For refugees who attended classes at the vocational schools, this meant sometimes extraordinarily long and strenuous commutes on public buses.

\subsubsection{Research Methodology}

Our study took place throughout 2016 and mainly reflects the school year 2015-2016, which was strongly influenced by the large numbers of arrivals during the summer of 2015 and concomitant reactions. During our research, new preparatory classes were formed, new teachers were engaged, new problems emerged and a number of sometimes contradictory regulations came into force. Our study was commissioned by the State Ministry of Culture and aimed to evaluate the educational practices in the preparatory classes focusing on the process of teaching and studying German. As the former curricula for preparatory classes aimed at children and younger students, our evaluation was meant to bring about suggestions of how to adapt the curriculum to the needs of more adolescent students.

Our research sites were suggested by our contractors. Both vocational schools had large and scattered campuses and offered a large variety of educational and vocational degrees, ${ }^{2}$ most of them as part-time classes. One school had 954 stu-

\footnotetext{
${ }^{2}$ For example in bakery, gastronomy, metal construction, automotive electronics or sanitary installation.
} 
dents, among them 53 asylum-seeking students in preparatory classes; the other had 1717, among them 73 asylum-seeking students, mainly from Afghanistan, Eritrea, Syria and Kosovo. During the year of our research, the number of asylum seeking students increased to 72 and 108, respectively, and there was a relatively high fluctuation among the students, due to changing statuses in the asylum application process, opening and closing of group accommodation facilities, or changing regulations that excluded students older than 18 from the lessons. One of the school campuses operated a boarding house for unaccompanied minor asylum seekers who attended the preparatory class on campus.

We started our research in February 2016 with field visits to both campuses and informal talks with the staff. Between February and June 2016 we carried out 11 expert interviews with the headteacher and teachers on both campuses, as well as six interviews with representatives of the school authority and other relevant stakeholders. For the expert interviews, we used an interview guideline that addressed the status quo of integration practices, success factors and difficulties, and left room for specific aspects that were of relevance for the interviewees. Furthermore, we attended lessons of the preparatory classes and a social event on campus and carried out participant observation, three group discussions and three guided interviews (in English and German) with the refugee students. Group discussions with the refugee students followed a participatory approach and were supported by visualizing tools in order to bridge language difficulties (see Fig. 9.2). During the sessions, the students were asked to evaluate their school programme with respect to structures, content, interaction with teachers and social aspects. Furthermore, we motivated them to thematise their future career aspirations, taking into account relevant framing factors such as status determination and secondary mobility for the purpose of family reunification. All interviews were taped and transcribed, and the informal talks and participant observations were documented in a research diary.

Our analysis followed the documentary method by Karl Mannheim, which has its foundations in the sociology of knowledge and praxeological approaches (Przyborski and Wohlrab-Sahr 2014). It aims to reconstruct collective orientations and the "modus operandi" of a specific field of action, which can be extracted during the interpretation process (Bohnsack et al. 2010). First, the topical sequences of each transcript were documented. In a second step, relevant passages for interpretation were selected. Those passages were reformulated in order to reveal the inherent meaning of what had been said. The next step entailed reflective interpretation, which aimed to uncover the action orientation embedded in the narration. In particular, this involved the explanation of the frameworks of orientations and habitus formations. One strategy of interpretation was to search for the limits and opportunities for action and to assess the potential for action from the perspective of the interviewees. By contrasting those action orientations and action potentials, collective orientations as well as diverging orientations and practices and their substantiation came to the fore. 


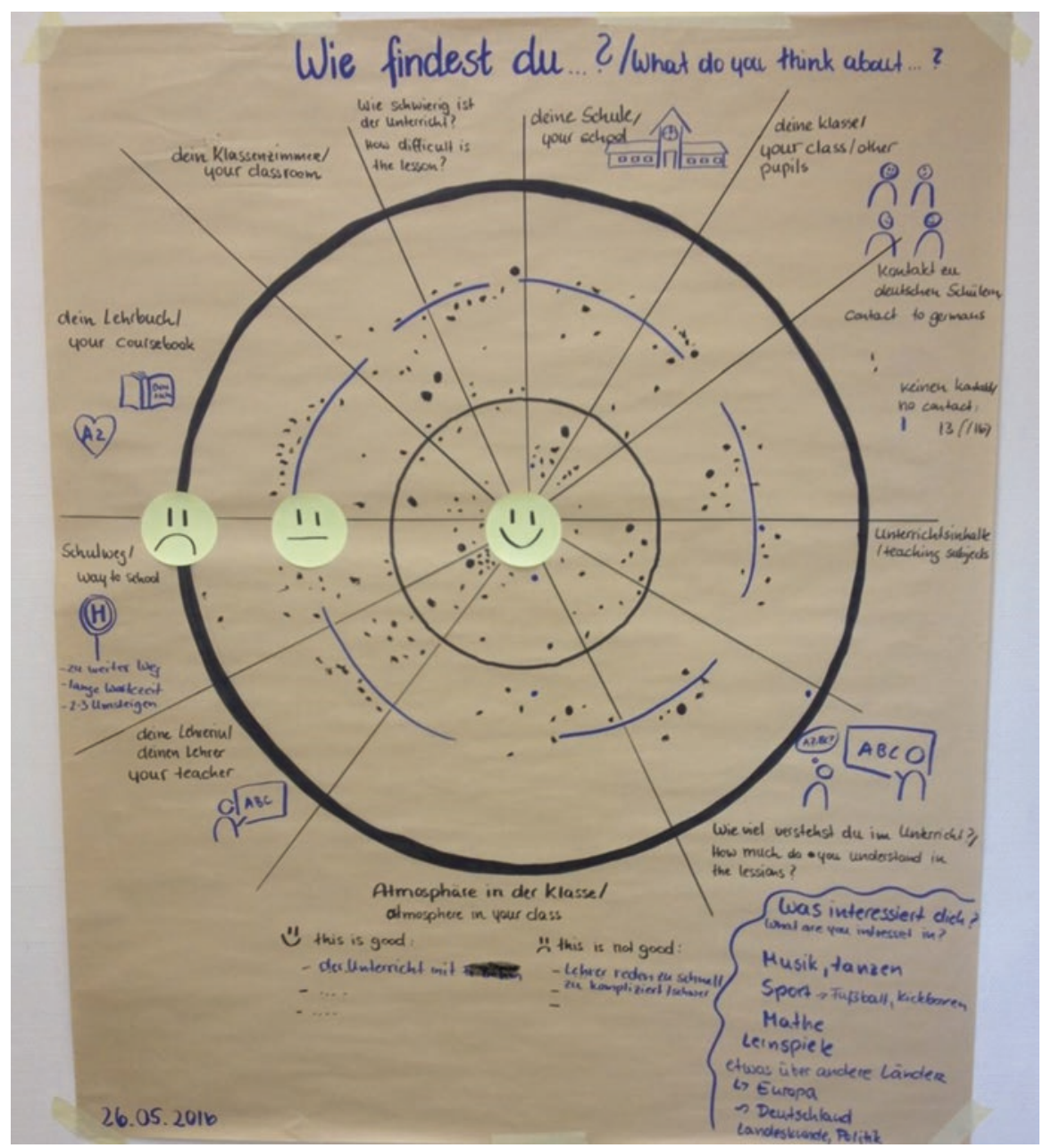

Fig. 9.2 Visualization tool for in-class evaluation. (Source: author's photo)

\subsection{Results}

From the perspectives of the interviewed groups of actors, we can differentiate three perspectives on integration: headteachers and school authorities focus on organizational aspects, teachers concentrate on language and classroom situations, while the students highlight aspects of social integration on and off campus. 


\subsubsection{Integration as an Organizational Challenge}

From an organizational point of view, the integration of asylum-seeking students in 2015 was a new coordination task for the respective schools and was, at the time of our study, still under development. From the perspective of the school authorities, the formation of those preparatory classes and their integration into the structure of the school was the main integration task

because, integration, in my understanding, not only means participation of individual students at the regular lessons, but it means integrating a class within the school system. (Representative of Regional School Authority, interviewed 12/02/2016, lines 13-18)

The headteachers of the vocational schools mainly focused on material issues in the preparation of those new classes, such as buying school books and dictionaries, as well as special equipment for the practical lessons, for example safety goggles for the welding shop. Possible consequences for the existing staff and students, such as xenophobic reactions or conflicts about scarce resources, were barely considered. Thus, the preparations did not include the school as a whole. It was not considered to unite the staff for the task of refugee integration, and likewise the German students were not prepared for integrating their new peers.

Hence, the class teachers of preparatory classes reported being left alone with all integration issues that needed cooperation with the "regular" teachers. This concerned for example the stepwise integration of refugee students in the practical lessons of "regular" classes (which was often refused by the instructors due to scarce capacities and the priority for trainees who were preparing for exams), the participation of refugees in internships (which required some extra engagement in terms of work permits or insurance, due to varying statuses), or practical questions regarding physical education (gender issues or lack of sports clothes). As a consequence, while the organization of systems integration was perceived as the duty of the headteacher, the social integration of the refugee students relied on the individual engagement of the preparatory classes' teachers. They usually reached out to other individual teachers who they knew were responsive to their requests, whereas some other teachers refused to teach "foreigners" at all.

Then I take the path of least resistance and approach those colleagues who I know will make the effort to integrate them [the refugee students], because that's not always easy. (preparatory class teacher, interviewed 08/02/2016, lines 613-615)

Some interviewees gave the impression that the preparatory classes' teachers and their work was perceived as marginal and not the subject of joint efforts.

With the end of the school year approaching, the question of future steps became more pressing for both school representatives and refugee students. While the students sometimes expressed very high educational goals and asked us researchers about possible pathways into university, teachers and representatives of the school 
authority were less optimistic about their future perspectives. They anticipated that, due to a lack of German language proficiency and general knowledge and skills, students would need further educational support to achieve a vocational degree. A number of problems were caused by the regulations for labour market access: for most apprenticeships, a secondary school certificate and a German language certificate are obligatory, neither of which were offered in the preparatory classes. This was also criticized by one teacher, who anticipated

that we are producing stockpiles, so to say: they have learned German, but then they cannot make anything out of it. (preparatory class teacher, interviewed 08/02/2016, lines 1251-1252)

Also regulations concerning the access to secondary education constituted a barrier for the continuation of refugee education: a number of orientation and preparatory programmes which were designed for teenagers without a secondary certificate are linked to the compulsory school age, which means that students above the age of 18 are not eligible for them. This also affects the preparatory classes. During our research, due to increasing refugee numbers and capacities lagging behind, this regulation was enforced and students turning 18 were sometimes not allowed to complete the one-year programme. Instead, they were recommended to enrol in a language course as part of other integration measures offered by various actors such as the labour agency or the Federal Agency for Migration and Refugees. Again, this regulation - which was enforced at the beginning of the second term of 2015-2016was heavily criticized by the teachers in charge of the refugee students, as they saw their integration efforts as being in vain:

There were students who just started in February, and they all had to leave.... They were told to look for regular integration classes. But they are only eligible for those classes when their asylum application is accepted. Those who are in the asylum procedure, or who only have a toleration status, are not eligible for those classes. (preparatory class teacher, interviewed 08/02/2016, lines 94-102)

Those asylum seekers who had sufficient knowledge of German after completing the preparatory class could look for an apprenticeship. At this point considerations of integration and the specifics of the region came to the fore. All interlocutors regarded the question of labour force development as essential for the further development of the regional economy. In this respect, the young asylum seekers can be regarded as a resource. At the same time, the integration of young migrants in education and the labour market is a central goal of the integration efforts. However, as the interviewees pointed out, this goal will only be achieved with great joint efforts from all relevant actors.

An actual example in this respect is the effort to introduce young people from the preparatory classes to the field of metalwork, since there is a strong demand for skilled workers in this area and accordingly a high motivation of the relevant actors to support the transition of the young asylum seekers into a dual education. 
We would like to attract them into metalwork, so that maybe one or two will later say they could imagine working in this field. Because that's what is needed in Erzgebirge: they are all very eager and are looking for apprentices in metal techniques-there is a very high demand. (headteacher, interviewed 04/02/2016, lines 593-597)

A problem could arise if educational certificates that are necessary to start an apprenticeship are missing, but this problem was perceived as solvable if chambers of commerce and employers cooperate (e.g. by easing the formal entry requirements into a dual education). From the point of view of our interlocutors, direct contacts between young people and employers are crucial, and the development of those contacts should be supported by mediating actors.

Employer and apprentice have to find each other to make this work out. (representative of regional school authority, interviewed 12/02/2016, lines 214-217)

Theoretically, both vocational schools have broad networks in this respect, as they have contacts with most of the small and medium-sized firms in the region that take apprentices. However, our research revealed that neither the headteachers nor the teachers felt responsible for or perceived to have capacity to do this kind of mediating work, and there were no additional staff at the schools (such as social workers) who could take over this task.

\subsubsection{Language Acquisition as a Basis for Social Integration}

As elaborated above, language plays a key role in the integration process, not only to reach educational goals, but also as a means for everyday communication, participation and recognition. Thus, for refugee students and teachers, learning the German language is the most important goal, and sometimes the only one. The skill level of the students was described as heterogeneous, and this not only refers to German language skills, but also general skills and competences, which ranged between near university entrance certificate and illiteracy. This was a big challenge for the teachers, who needed to flexibly switch between the various skill levels, but it also imposed a burden on those students who were more advanced.

You cannot speed up learning a new language. And they know it, they always say 'Step by step, slowly, slowly'. But some are learning quickly, and others more slowly. And those who learn easy, they are losing patience to listen to the others, who strive and want to speak, and they want to speak because they are faster. That's really challenging. (preparatory class teacher, interviewed 07/04/2016, lines 243-261)

A further problem is the fluctuation of participants in the preparatory classes, as students are continuously allocated to the classes throughout the year, and some have to withdraw from class during the year, due to changing asylum statuses or the changing allocation of refugee housing. In the teachers' perceptions, the goal to acquire enough German to start an apprenticeship after the end of the preparatory class will be rather difficult to achieve under these conditions. 
The teachers also anticipated a lack of opportunities to meet and enter into social interaction with German peers or Germans in general.

But how are they gonna do it? You don't go out in the street and ask: 'Do you want to have contact with me?' 'Contact' is the favourite word of some students. But this only works in natural everyday situations. That's why it's so important to get them into an apprenticeship, to get them into a job, because that's the only way it really works. Everything else is fake. (preparatory class teacher, interviewed 08/02/2016, lines 1212-1220)

However, the possibility to create opportunities for social interaction on campus were not used, and in some cases even restricted: The refugee students were educated separately to the German students, and also on campus there was a segregated situation, which culminated in different schedules for the breaks between lessons "to avoid conflicts", as one of the headteachers stated.

\subsubsection{Challenges of Social Integration - The Students' Perspective}

What is the view of the students on their language class? We addressed this question during group discussion, supported by a visualization tool (Fig. 9.2).

All students assessed their language understanding during lessons as very good, and all said they enjoyed the lessons. However, there was a shared desire to learn more than just German. The students would have also liked to take further subjects such as mathematics, biology or history in order to complete their education. They were interested in history, geography and the political system of Germany and regretted that these were not subjects in their lessons. Considering their language competences outside the classroom, many were dissatisfied. One student stated that he would not dare to approach German age peers due to his poor language proficiency. Ninety percent of the refugee students stated they never had any contact with German students, mainly due to the fact that they did not meet during classes. Many reported a feeling of isolation:

One problem is that we are all from Afghanistan or other countries. We want to study German with Germans, because this is good for our progress. That's the only problem here, the rest is fine. (Student M., research diary of participant observation, 01/06/2016)

During our participant observation of a football match on campus, we asked the German students if they knew where the refugee team came from. No one identified them as fellow students from the same campus. This might be partly due to the specifics of a vocational school with mostly part-time students, so that there is no continuous presence of peers on campus. In any case, the segregated situation was not seen by the teachers or headteachers as a problem they should take care of.

As stated above, the possibility to conduct German conversations outside the classroom would strongly support language skills. Furthermore, everyday social contacts and participation opportunities for migrants are the basis for social integration and for them finding a place in their new surroundings. However, if we consider 
the housing situation of the young students, it is clear that those opportunities are scarce. Some live with their families or in group accommodation in various municipalities of the county, while others live in the boarding house of the vocational school, directly on campus. Their daily life outside school is characterized by social isolation, reinforced by the fact that the public transport infrastructure is poor and there are no other means of transport for the students.

\begin{abstract}
I have students from $\mathrm{O}$. which is one full hour from the bus station. But they live on the outskirts, so that they have to take one more train or bus for half an hour. (...) We have a group accommodation for minors in L., that's not that far from here, but the connection is really bad. From L. to P., then from P. to W., and so forth. They have to leave at 5.30 every morning. When I get up in the morning, I think 'poor boys, they are already on the road.' But still they arrive with a smile and are happy, that they can go to school. (preparatory class teacher, interviewed 08/02/2016, lines 339-359)
\end{abstract}

The distant accommodation not only makes the daily trip to school onerous, but generally impedes a self-determined life, in which the young people can orient themselves and interact with other young people. Also, the unresolved residence status and the sometimes unclear perspectives for long-term stay have a negative effect on social integration. Concerning the specific problems the asylum process imposes, there are no provisions in the rural area that are specific to this target group and their needs and interests. For example, there are neither lawyers working on asylum in the region, nor specialized counselling centres. In addition, the job centre is far away. Thus, many students plan to move to bigger towns or cities as soon as possible, as these offer more possibilities for employment, education and for social contacts with peers.

When I talked to A., he told us he was looking forward to moving to S-town tomorrow. He doesn't like O-town, as he has no public transport ticket and is struck in the town. In S-town he will move in with a friend who is also from Syria. Here, in O-town, he is all alone. After moving to S-town, he will also be able to visit C-town more frequently, as it is much more accessible. He likes the town and he will get the opportunity to work in an Arabic restaurant. (research diary of participant observation, 01/06/2016)

A further obstacle to social integration in the region is xenophobia and racism, which affects the students directly. Students reported that people insulted them when riding on the public bus, and some even experienced physical attacks at their accommodation facilities. Some students perceive their classroom as a shelter, and they only go out in larger groups, because they fear being attacked. We were also told of rumours in the schools and of undifferentiated reports in the regional newspapers, which address and partly also problematize the presence of refugees in the vocational school. However, the school staff did not actively oppose these xenophobic activities. Those reactions and underlying attitudes of the local population were rather perceived as normal and unchangeable, as the following citation shows:

I also do field trips with larger groups even though we are being recognized on the bus and on the train and sometimes we annoy people. The students don't do any harm, but if I am arriving with a group, and there are ten black students, who raise a lot of attention, then you experience just the normal life here, so sometimes you are harassed and shouted at. (preparatory class teacher, interviewed 08/02/2016, lines 930-935) 


\subsection{Discussion and Conclusion}

The main aim of the research presented in this chapter was to investigate the role of the local in the field of educational integration in vocational schools in Germany. The significance of this field of research is highlighted with regards to the age structure of refugees, who are mainly younger than 25 and often have not finalized their education in their home countries. In order to find a way into the German labour market, not only language knowledge, but also knowledge about the specifics of the labour market and the German education system are necessary. From the perspective of state actors, vocational schools are a preferable environment in this respect, as they focus on the acquisition of practical skills, and are more easily accessible than academic education, given refugees' limited knowledge of German. With the choice of our case study, we also wanted to highlight the relevance of contextual factors, namely the geographical setting, the social and economic situation, and the history of the case study site, notably with respect to migration issues. Additionally, we wanted to highlight the connectivity of policies, practices and discourses in our field of research.

In our analysis, we were guided by research questions that focused on the very meaning and contextualization of the term "integration", as we assumed that the individual and collective framing of this term strongly influences concrete practices of integration. From our own understanding, we followed the general outlines of the term "integration" from social theory, which differentiates between systems and social integration with its main aspects of culturation, placement and interaction, but we also integrated the perspectives of transnational and post-migration approaches, which stress the intercultural and anti-racist aspects of immigrant incorporation.

Considering the interpretation of "integration" in the understanding of the main stakeholders in the field like headteachers and school authorities, we clearly identified the priority of systems integration, meaning the implementation of preparatory classes, based on the guidelines and regulations of the authorities. The authorities' engagement mainly entailed organizational tasks and showed a segmented understanding of integration as giving a formal frame in terms of physical settings (classrooms), devices (dictionaries etc.), personnel (teachers) and time (school schedule), rather than taking the perspective of the individual and his or her needs from a more holistic perspective. This interpretation and these practices can be comprehended from the professional role of the stakeholders as public servants in a segmented culture of planning, and corresponds to their general professional role. However, it hinders focussing on the long-term integration of the refugee students and possible integration paths, such as arranging internships or further pre-employment measures. The respondents did not feel responsible in this respect, but rather awaited necessary system adjustments. Such adjustments would come too late for the refugee students from 2015-2016. 
The perspective of the teachers, on the other hand, is guided by their role as language teachers and pedagogical professionals. While they predominant focus on the organization of everyday teaching, they are aware of mismatches between the formal regulations and their application. They build up personal relationships with the students and thus also introduce the category of emotion to the topic of integration. However, they perceive their own agency as limited, which is due to their rather marginal position in the school boards on the one hand, and the specifics of the region on the other, as there are few experiences with foreigners in the area and parts of the population show strong signs of xenophobia.

The refugee students certainly have the most holistic view of integration, but the least amount of action autonomy, so they are barely able to stimulate change. For them, school is not just a place of learning, but constitutes the primary place of everyday integration through contact with their teachers and peers. At the same time, they cannot plan ahead in terms of time or space, as their future depends heavily on their asylum procedure, and repatriation or onward migration is possible at any time. Thus their classrooms and their relations to their teachers and peers are islands of stability in an otherwise uncertain future. In class, they aim to acquire knowledge which can be helpful in their future life. However, they are confronted with a system that is rather inflexible with respect to their peculiar situation.

What do these results mean in generalized terms? Based on the geographical and structural specifics of our case study, we have shown how the issue of refugee reception and integration is embedded into broader lines of conflict in a specific region or policy field and that the effectiveness of reception and integration measures is dependent on political culture in general.

The practices and policies we have found show the contradictions between a monolingual, sedentary culture of education and the supposed temporality of the stay of adolescent refugees. On the one hand, the refugees' provisional situation refers to their unclear asylum status (which was, at the time of our survey, subject to multiple re-regulations, which mostly meant aggravations for the asylum procedure) and, on the other hand, to the assumption that they will not stay put, following the predominant experience of the region, which is outmigration. Against this background, it is rather unlikely that further efforts will be made to ensure a more sustainable integration of the refugee students, even though the general conditions are rather favourable.

\section{References}

Bauer, A., \& Schreyer, F. (2016). Ausbildung von unbegleiteten minderjährigen Flüchtlingen: Sinnvoll ist Unterstützung über Volljährigkeit hinaus (IAB Kurzbericht 13/2016). Nürnberg: Institut für Arbeitsmarkt- und Berufsforschung.

Baur, R. S., Ostermann, T., \& Chlosta, C. (2004). Der weite Weg von der Mehrsprachigkeit zur Sprachförderung. In Y. Karakşoğlu \& J. Lüddecke (Eds.), Migrationsforschung und Interkulturelle Pädagogik. Aktuelle Entwicklungen in Theorie, Empirie und Praxis (pp. 161170). Münster/New York/München/Berlin: Waxmann. 
Behrensen, B. (2007). In der Warteschleife: Analysen zur Beschäftigungsfähigkeit Asylsuchender und geduldeter MigrantInnen: Forschungsergebnisse des Teilprojekts "ABA - Analyse der Beschäftigungsfähigkeit Asylsuchender" im Rahmen der EQUAL-Entwicklungspartnerschaft "SAGA-Selbsthilfe, Arbeitsmarkt und Gesundheit von Asylsuchenden". Osnabrück: Eigenverlag.

Berry, J. W. (1984). Cultural relations in plural societies: Alternatives to segregation and their sociopsychological implications. In N. Miller \& M. B. Brewer (Eds.), Groups in contact: The psychology of desegregation (pp. 11-27). New York: Academic.

Bohnsack, R., Pfaff, N., \& Weller, W. (Eds.). (2010). Qualitative analysis and documentary method in international educational research. Opladen: B. Budrich.

Bowskill, M., Lyons, E., \& Coyle, A. (2007). The rhetoric of acculturation: When integration means assimilation. British Journal of Social Psychology, 46(4), 793-813.

Braun, R., \& Simons, H. (2016). Familien aufs Land. In S. Franke \& H. Magel (Eds.), Flüchtlinge auf Land? (pp. 20-29). https://www.hss.de/fileadmin/user_upload/HSS/Dokumente/_ Publications_/161229_AMZ-106_INTERNET.pdf. Accessed 16 Apr 2019.

Bundesamt für Migration und Flüchtlinge (BAMF). (2016). Das Bundesamt in Zahlen 2015. Asyl, Migration und Integration. Nürnberg: BAMF.

Bundesministerium des Innern (BMI). (2016). Migrationsbericht des Bundesamtes für Migration und Flüchtlinge im Auftrag der Bundesregierung. Berlin: Migrationsbericht 2015.

Esser, H. (2000). Soziologie. Spezielle Grundlagen, Band 2: Die Konstruktion der Gesellschaft. Frankfurt/M/New York: Campus Verlag.

Foroutan, N. (2015). Unity in diversity: Integration in a post-migrant society. Policy Brief. Bundeszentrale für politische Bildung. http://www.bpb.de/gesellschaft/migration/kurzdossiers/205290/integration-in-a-post-migrant-society. Accessed 22 Feb 2018.

Gag, M., \& Schroeder, J. (2014). Monitoring und Bildungsberichterstattung mit Fokus auf Flüchtlinge und Asylsuchende - ein Beispiel. In M. Gag \& F. Voges (Eds.), Inklusion auf Raten. Zur Teilhabe von Flüchtlingen an Ausbildung und Arbeit (pp. 29-48). Münster: Waxmann Verlag.

Georgi, V. (2015). Integration, Diversity, Inklusion. Anmerkungen zu aktuellen Debatten in der deutschen Migrationsgesellschaft. DIE Zeitschrift für Erwachsenenbildung II/2015, 25-27.

Glorius, B. (2008). Report from Germany. In J. Doomernik \& M. Jandl (Eds.), Modes of migration regulation and control in Europe (pp. 81-104). Amsterdam: Amsterdam University Press.

Gogolin, I. (2010). Interkulturelle Bildungsforschung. In R. Tippelt \& B. Schmidt (Eds.), Handbuch Bildungsforschung (pp. 297-315). Wiesbaden: Springer.

Gurski, L., \& Rother, T. (2018). Wie erleben geflüchtete Jugendliche Schule in verschiedenen Lerngruppen? Erfahrungsberichte von inkludierten und (noch) nicht inkludierten Flüchtlingen. In P. große Prues (Ed.), Inklusion im Rahmen von Schule - eine Aufgabe, viele Möglichkeiten Ein Sammelband von Studierenden der Universität Osnabrück (pp. 173-184). Osnabrück: Selbstverlag.

Heinrichs, K., Kärner, T., Ziegler, S., Feldmann, A., Reinke, H., \& Neubauer, J. (2016). Die Implementierung neuer Konzepte zur Beschulung von Flüchtlingen und Asylsuchenden Herausforderung und Chancen aus organisations- theoretischer Perspektive. Gruppe. Interaktion. Organisation, 47(3), 231-241.

Hersi, A. (2014). Discourses concerning immigrant integration: A critical review. European Scientific Journal, 1857-7881.

Herwartz-Emden, L. (2007). Migrant/-innen im deutschen Bildungssystem. In BMBF (Ed.), Migrationshintergrund von Kindern und Jugendlichen: Wege zur Weiterentwicklung der amtlichen Statistik (pp. 7-24). Bonn: BMBF. 
Kelch, M. (2016). Sachsens Schulen nehmen immer mehr Flüchtlinge auf. Blogbeitrag vom 22.03.2016. http://www.bildung.sachsen.de/blog/index.php/2016/03/22/sachsens-schulennehmen-immer-mehr-fluechtlinge-auf/. Accessed 13 Apr 2016.

Kühn, G., \& Gawlick, E. (1994, November). Weiterbildung von Aussiedlern unter besonderer Berücksichtigung fachübergreifender Kompetenzen. Info-Dienst Deutsche Aussiedler, 61, $20-28$.

Lockwood, D. (1964). Social integration and system integration. In G. K. Zollschan \& W. Hirsch (Eds.), Explorations in social change (pp. 244-257). London: Routledge \& Kegan Paul PLC.

Mercator-Institut für Sprachförderung und Deutsch als Zweitsprache und Zentrum für LehrerInnenbildung der Universität zu Köln (Ed.). (2015). Neu zugewanderte Kinder und Jugendliche im deutschen Schulsystem. Bestandsaufnahme und Empfehlungen. http://www. mercator-institut-sprachfoerderung.de/fileadmin/Redaktion/PDF/Publikationen/MI_ZfL_ Studie_Zugewanderte_im_deutschen_Schulsystem_final_screen.pdf. Accesses 15 Sept 2016.

Metzner, F., Zimmer, I., Wolkwitz, P. Wlodarczyk, O., Wichmann, M., \& Pawils, S. (2018). Soziale Unterstützung bei unbegleitet und begleitet geflüchteten Jugendlichen und jungen Erwachsenen nach der Ankunft in Deutschland: Ergebnisse einer Befragung in >Willkommensklassen< an Hamburger Berufsschulen. Zeitschrift für Flüchtlingsforschung 2(1), 3-31. https://doi. org/10.5771/2509-9485-2018-1-3.

Nohl, A.-M. (2010). Konzepte interkultureller Pädagogik. Eine systemische Einführung. Bad Heilbrunn: Klinkhardt.

Paulsen, H., Kortsch, T., Kauffeld, S., Naegele, L., Mobach, I., \& Neumann, B. (2016). Anerkennung der beruflichen Kompetenzen von Flüchtlingen - Ein Beitrag zur Integration. Gruppe. Interaktion. Organisation, 47, 243-254.

Pettigrew, T. F. (1988). Integration and pluralism. In P. A. Katz \& D. A. Taylor (Eds.), Eliminating racism. Profiles in controversy (pp. 19-39). New York: Springer.

Pries, L. (1996). Transnationale Räume. Theoretisch-empirische Skizze am Beispiel der Arbeitswanderung Mexiko-USA. Zeitschrift für Soziologie, 25, 437-453.

Pries, L. (2003). Transnationalismus, Migration und Inkorporation. Herausforderungen an Raumund Sozialwissenschaft. Geographische Revue, 2/2003, 23-39.

Przyborski, A., \& Wohlrab-Sahr, M. (2014). Qualitative Sozialforschung. Ein Arbeitsbuch. München: Oldenbourg Wissenschaftsverlag.

Riegel, C. (2009). Integration - ein Schlagwort? Zum Umgang mit einem problematischen Begriff. In K. E. Sauer \& J. Held (Eds.), Wege der Integration in heterogenen Gesellschaften. Vergleichende Studien (pp. 23-40). Wiesbaden: Springer VS.

Scheiermann, G., \& Walther, M. (2016). Flüchtlingsintegration durch berufliche Bildung - neue Herausforderungen und improvisierte Lösungen in einem alten Handlungsfeld. bwp 30. http:// www.bwpat.de/ausgabe30/scheiermann_walter_bwpat30.pdf. Accessed 16 Apr 2019.

Schneider, J., \& Crul, M. (2010). New insights into assimilation and integration theory: Introduction to the special issue. Ethnic and Racial Studies, 33(7), 1143-1148. https://doi. org/10.1080/01419871003777809. Accessed 16 Apr 2019.

Speer, M., \& Klaus, T. (2015). Der lange Weg zur Arbeit. Qualitative Studie zu räumlichen Möglichkeiten und Hindernissen einer Partizipation von Flüchtlingen am Arbeitsmarkt am Beispiel von vier Standorten in Niederbayern. https://www.fluechtlingsrat-bayern.de/tl_files/ PDF-Dokumente/Der\%20lange\%20Weg\%20zur\%20Arbeit\%20bfr-Bleib\%20in\%20Bayern. pdf. Accessed 16 Apr 2019.

Treibel, A. (1999). Migration in modernen Gesellschaften: Soziale Folgen von Einwanderung, Gastarbeit und Flucht. München: Beltz Juventa.

Vereinigung der Bayerischen Wirtschaft (vbw) (Ed.). (2016). Integration durch Bildung. Migranten und Flüchtlinge in Deutschland. Gutachten. Münster: Waxmann. 
Vogel, D., \& Stock, E. (2017). Opportunities and hope through education: How German schools include refugees. Brüssel. http://www.fb12.uni-bremen.de/fileadmin/Arbeitsgebiete/interkult/ Vogel/17_Vogel_Stock_Refugee_Schools_Germany.pdf. Accessed 16 Apr 2019.

Wirtschaftsförderung Erzgebirge GmbH. (2014). Standortprofil Erzgebirge/Erzgebirgskreis. http://www.wfe-erzgebirge.de/. Accessed 16 Apr 2019.

Open Access This chapter is licensed under the terms of the Creative Commons Attribution 4.0 International License (http://creativecommons.org/licenses/by/4.0/), which permits use, sharing, adaptation, distribution and reproduction in any medium or format, as long as you give appropriate credit to the original author(s) and the source, provide a link to the Creative Commons license and indicate if changes were made.

The images or other third party material in this chapter are included in the chapter's Creative Commons license, unless indicated otherwise in a credit line to the material. If material is not included in the chapter's Creative Commons license and your intended use is not permitted by statutory regulation or exceeds the permitted use, you will need to obtain permission directly from the copyright holder.

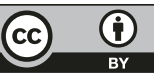

